\title{
THE EFFECTS OF LAND TENURE POLICY ON THE ENVIRONMENT IN THE GAMBELLA REGION
}

\author{
CHUOL KOMPUOK
}

AFRICAN INSTITUTE OF GOVERNANCE AND DEVELOPMENT (AICAD),

ETHIOPIAN CIVIL SERVICE UNIVERSITY

CKOMPUOK2OI4@GMAIL.COM

An attempt is made to investigate the consequences of land tenure policy on the environment enhancing reforestation as a means of ascertaining tenure security in the Gambella region. This paper sheds light on the accelerated pace of deforestation in the study area and its impact on the environment. The theoretical and conceptual issues of the interrelation between reforestation, deforestation, land tenure system, and other socio-economic indicators have been given due attention in the literature review. Research methodology gives much focus on qualitative data analysis that uses ranges of data collection approaches; FGD, KII, semi-structured household interviews with the inclusion of secondary data reviews. The paper considers the effect of land tenure system on the environment and discusses the landholding system in the study area, including customary land rights among the Nuer, the Anywaa, and the Majangir. To this effect, external factors and urban expansions are addressed with the view to understanding the impact of socio-cultural practice on physical environment perception and management. A conclusion and policy implications are also discussed. 


\section{Introduction}

Even though there is a wide recognition of the importance of land policy to agrarian development, there is no clear and universally recognized blueprint to define what an appropriate land policy ought to be. (EEA/EEPRI, 2002: 4) Ethiopia is one of the few countries in Africa that has not made any major change in its basic land policy since the radical land reform of 1975 when the government nationalized land and distributed it to the peasantry, thereby eliminating a highly skewed landholding pattern. In modern as well as traditional communities, the way in which property rights to land are defined is of great importance for economic growth, the efficient use of this resource, proper governance at the local level, poverty reduction, and the opening up of productive opportunities for the poor.

It is also believed that the landholding system in less developed nations is not a purely economic affair; people's culture and identity play a significant role. That is partly why land-related issues usually generate severe emotional reactions in rural areas including Gambella. Obviously, for the rural residents of most developing countries land is the primary means of production from which one is able to generate a livelihood for the household (Deininger and Feder, 2002). It is also the main asset that farmers have to further accumulate and transfer into a form of wealth for future generations (Berhanu et al., 2003).

Accordingly, the land size they own, "the feeling of security that they have on their holdings, and the process through which land disputes are adjudicated all affect the household's income" (Hosaena, 2010: 1). Moreover, "their incentive to work and invest, their desire to use their land sustainably, and even their social and economic position in their respective communities" (Ibid.) are impacted. "In predominantly agrarian societies all these factors combine to affect agricultural output and productivity, and along with it," (Ibid.) the economic development of the country. Ostensibly, land policy in developing countries is a vital albeit sensitive part of the overall development policy that the government has to consider if the hope for rapid economic growth and the objective of poverty alleviation are to materialize.

Since land is the main asset in the life of Ethiopian rural communities including Gambella, the direction in which property rights over land is defined and, among economic agents, the efficacy in administering and resolving conflicts around it are important for the country's overall development. 
Several scholars and researchers have also associated the country's unfortunate state and rate of development with its inability to get rid of many problems related to its land policy and administration, in particular, and agrarian issues, in general (Beyene, 2017; Binayaw, 2015; Dessalegn, 1984, and Berhanu et al., 2003). This research aims to examine the effects of land tenure policy on the environment in the Gambella region. This is specifically to investigate whether the existing land tenure systems and institutions and the weaknesses or strengths of land rights have an adverse effect on environmental degradation.

\section{Literature review}

The interrelation between reforestation, deforestation, land tenure system, and other socio-economic indicators has been given due attention in recent studies. The macro-economic policies' performance, in general, and agricultural productivity, in particular, depend on the natural resource base (Place and Otsuka, 2000; CrisologoMendoza and Van de gaer, 2001). This implies that policy-makers should identify and implement measures that enhance agricultural productivity while retaining the resource base. A resource base can be maintained with the application of sustainable land tenure policies, though sustainability seems to be inconsistent with the current Ethiopian land tenure policy. To reverse this trend, a study needs to be undertaken at a community or household level by identifying factors that enable the community to engage in the long-term investment in the land tenure system.

Place and Scherr have developed a theoretical model of land use and reforestation. The model extends over 3 periods. In the initial period, a household decides whether to convert woodland to agricultural land; the decision depends on the benefit of forests or tree crops vis-à-vis agricultural land or annual crops. When a farmer makes a decision to clear the forest, he takes into account the availability of family labor and the expected profit from either forest or agricultural products. The entire decisionmaking process hinges on the land tenure system that is prevalent in the study area.

Place and Otsuka (2000) applied the standard household production model to Uganda where parishes were taken as units of observation. Their empirical findings suggest that changes in shares of land area (from agricultural lands to forests and vice versa) are affected by the prevalence of land tenure systems. The land tenure systems of the study area are classified into four types, namely, exclusive tenure, open tenure, resident tenure, and absentee tenure. Other explanatory variables include population density, the population growth rate, rainfall and the related climatic conditions as well as the distance to nearby towns.

Another study related to land tenure systems and deforestation in the study area was conducted in Ghana (Benneh, 1987). The results of this study indicate that "If trees are planted, individual tenure security is enhanced and rights to transfer land to desired heirs are strengthened. This is because the work effort for planting trees is rewarded by strong individual land rights under customary land tenure" (Quisumbing and Otsuka, 2001: 11). Similar results were observed by Quisumbing et al. (2001) and Shepherd (1991). 


\section{Methodology}

The research was basically a qualitative type that used ranges of data collection approaches, focus group discussions (FGD), key informant interviews (KII), and semi-structured household interviews with the inclusion of secondary data reviews for the purpose of this study. The emphasis in such a method was to have an in-depth understanding of what people feel and think and why (Laws et al., 2003). Findings from the study may well have wider relevance for the policy prescriptions in the study area Gambella with respect to the effects of land tenure policy on the environment.

\section{The effect of land tenure system on the environment}

Although land policy is widely considered vital to agrarian development, there is not a universally agreed pattern of the best land policy to be pursued. In some cases, the efficacy of land policy in bringing agricultural development partly depends on socio-cultural and geographic variables that significantly vary from one country to another. Even within one country, various types of landholding systems exist depending upon history and the farming systems that prevail in the different regions of the country or the existing agro-ecological zones. In spite of these differences, researchers have tried to come up with certain basic principles with the aim of formulating a land policy that helps generate higher levels of productivity in agriculture while also maintaining the important consideration of equity. These principles change through time, as more information is gathered from country experiences. All these differences and patterns are expected to have a significant effect on environmental factors, in general, and land tenure regimes, in particular.

A World Bank study identified three criteria for the efficient management of land. These are (a) owner-operated family farms as being efficient and thus desirable, (b) freely operated land markets to permit land transfers to more efficient and productive users, and (c) the need for a more equitable distribution of assets (Deininger and Binswanger, 1999). While the three different approaches may have different effects on productivity and investment, their effect on the environment, in general, and deforestation, in particular, has not been articulated.

One of the few African countries that made no significant changes in their land reform policies is Ethiopia, where the state nationalized land and distributed it to the peasantry. This was meant to eliminate the highly skewed landholding pattern. Before 1975 most of the fertile arable land belonged to the absentee landlord; peasants were forced to surrender as much as two-thirds of the produce to the former. Even though the 1975 land redistribution act may have practically addressed equity consideration, its effect on agricultural productivity was not substantial. As a result, famines keep on recurring and deforestation continues at an accelerated pace. The newly established EPRDF-led government in 1991 chose to keep intact the 1975 rural land proclamation, thereby exacerbating continuing land fragmentation, the extended use of marginal land, and continuing deforestation (Shimelles et al., 2009). The justifications behind the absence of interest on the part of the government to 
consider discussing alternative tenure regimes emanate from a belief that the recent land policy essentially serves the interests of agricultural development in the country better than its alternatives. This belief has never been empirically tested. Moreover, the present land policy in the country vis-à-vis its effect on the environment has not been addressed at all. The fact that there is substantial variability in the landholding system in Ethiopia has made it impossible to reach some consensus on the interaction between land and the environment. To this end, we can arguably conclude that the peasant farmers of Gambella fall prey to variation in landholding systems in the entire country as policy-makers cannot reach a consensus on the interaction between land tenure regimes and the environment.

\subsection{Landholding systems in the study area}

In many cases, it is recognized that Ethiopia's pre-1975 land tenure system, which has not been researched, is considered to have been the most complicated in the world (Dessalegn, 1984; Dejene, 1999). Thus, little is known of the land tenure system in Gambella and very little study has been done so far. An attempt that could have shed light on the existing tenure system with different dynamics across the region, given that different ethnic groups of different livelihoods inhabit Gambella, has not been undertaken. Therefore, I will highlight three ethnic groups, namely, the Nuer, the Anywaa, and the Majangir; the remaining two ethnic groups (Komo and Opo), constituting less than 5\% of the total population of the Gambella region in Ethiopia (Central Statistical Agency of Ethiopia, 1994), have similar backgrounds as the three others and will not be discussed.

Sedentary agriculture has become the dominant form of supporting livelihood for some ethnic groups in the region, particularly the Anywaa, since ancient times. Other ethnic groups, such as the Nuer, are mostly "pure" pastoralists who always roam about the area with their cattle in search of grazing land. Among the Nuer, crop production is not the basic mode of livelihood, only a small plot of land is used for farming and women are engaged in this very small-scale farming. Fresh maize and sorghum are grown for temporary consumption. In the ancient days, farming was meant for women and men were engaged in cattle rearing; as farm size was limited, not much labor or other input was required.

\subsubsection{Customary land rights among the Nuer}

The process of land acquisition and the system of land tenure in the Nuerland (eastern Jikany Nuer) areas are not much different from the land tenure system in the other parts of sub-Saharan Africa and Ethiopia; communal ownership of land is widespread. The system came into an abrupt halt when the previous socialist government adopted the land proclamation of 1975 with the nationalization of all rural lands abolishing previous tenure arrangements in the country (Bereket, 2002).

In Nuer culture, land is communally owned according to the kinship arrangements. When new land is discovered, the village chief (land master) in collaboration with the council of elders plays a pivotal role in making the necessary arrangements 
to perform the ritual ceremony by slaughtering the bull, a symbol of acquiring new land. Children of future generations are entitled to inherit the newly acquired land. The soil of that particular area is blessed after the land master performs the activities and the land is recognized as theirs; from the time of the ceremony, no other person can claim rights to this newly acquired land.

The process of land acquisition leads to the individual ownership of farmland and homestead through forest clearance, followed by necessary investments to prove one's ownership rights. For centuries, investment in Nuer culture has not meant planting trees but piling up the burnt cow dung. It is also true that even the greatgrandchildren do the same and that continues for generations, particularly in the upland areas. Investment in tree planting is relatively new in Nuerland; they plant new trees to acquire land for the coming generations. In earlier times, there was a taboo against planting trees. In other words, there was a belief that if a tree was planted, there was a likelihood that the persons who had planted the tree would die before the tree grew. This belief was taken as an impediment to tree planting for a long time.

According to the Nuer, settlement patterns based on kins/kiths have a stabilizing effect on land ownership; whenever a conflict/dispute arises, it can be easily settled with no further complications. Though the Nuer are pastoralists by their very nature, their livelihood patterns have changed from being "pure" pastoralists to being farmers and cattle rearers as well. They have two types of settlements: those at the bank of the Baro River and upland settlements. When the water level of the rivers drops, the Nuer move to the bank of the Baro River to do all the necessary farming and planting. Soil preparation and the planting of the crops take place when the soil is wet, which tends to help the germination of the newly grown crops; then the soil dries out again, which is followed by cattle camp settlement. The roads of the settlement are passable only when the water level is low and until the next season begins, that is, when the rains fall. This implies that settlements at the bank of the river are less permanent. Upland settlements are thought to be permanent since all the valuable belongings are kept in the uplands where cattle mangers are built.

\subsubsection{Customary land rights among the Anywaa}

The land tenure system in the Anywaa setting has some similarities with the Nuer land tenure system of communal ownership. According to the Anywaa, chiefdoms have their own kings who manage the matters related to land allotment/allocation or disputes arising from unclear boundaries. Even if the ownership right is given to individual owners, the king has the ultimate power over the land as he is the ruler of the whole land. In ancient times, the Anywaa king played a key role in managing the resources; his permission was required if someone was to acquire land. Without him (the king), there was no reason for a single community to take initiative to find new land and give a name to it. Members of the community carried out all discoveries and innovations through him (the king). Anywaa kings are powerful and well-respected, which is a sign of their legitimate power over the land vested in him by the com- 
munity and God. They take control of vast areas of land and no action can be taken without their knowledge. Each chiefdom has boundaries and the king helps resolve disputes relating to land titles. This is the true indication of the fact that Anywaa kings are the landlords and have the power of allotting land to the inhabitants. They have the right to institute laws and orders. Given all the powers vested in their kings, peasants have no choice but to work for the rulers, and they are compensated with a part of the produce.

The preceding discussion of the landholding system among the Anywaa was put in a historical perspective by a national proclamation in 1975 that made the landholding system rather communal and limited the king's power to settling disputes related to land; otherwise, after the implementation of this act, land has been communally owned and periodically allotted.

The Anywaa have two types of settlements: those at the riverbank and the upland settlements. The patterns are almost the same as those of the Nuer, but the Anywaa are purely sedentary agriculturalists. A riverbank is more devoted to agricultural activities and it is more demanding than an upland; however, the former is more fertile. As the riverbank is more susceptible to flood damage, many settlements are found in the uplands. Settlement and farming at the bank of the river are feasible only when the water level falls. Such settlement continues to exist until the next season sets in.

Like in the case of the Nuer, an informal land market operates also in the Anywaa territory with no involvement of the government bodies. Land market transactions are made haphazardly at the bank of the river where demand of the farmland is at its peak.

\subsubsection{Customary land rights among the Majangir}

The customary land tenure system of the Majang people is almost the same as that of the Nuer since land is owned communally. Land is a common property for all the indigenes, especially the Majangir. People who rule over the lands are the council of elders who have the right to allocate land to the lineages and, at the same time, settle disputes arising from land-related conflicts. The Majang people believe that land belongs to the Majangir and the community in question. It is also true that there is no tradition of planting trees as a way of acquiring title deed.

Majangir livelihoods rely mainly on shifting cultivation; maize, sorghum, hunting and beekeeping play a significant part in their subsistence. With respect to livestock rearing, they only raise chickens and sell honey; this is because the area is infested with tsetse fly. They also participate in gathering forest products and wild plants. 
Land is considered to be losing its fertility on a yearly basis as the extent of weeds increases over the cycle. Among the Majang people, shifting cultivation is quite common; there exists a series of field types in a fixed sequence over space, with the provision for the renewal of the soil (Stauder, 1971). The fallow period is about 10-15 years until the forest regenerates. Abandoned fallow lands were normally seen around the Majangir settlements in the past. But due to population pressure from within and the settlers (highlanders) from the northern part of Ethiopia, the fallow period is reduced to zero, implying that there is constant farming on the same land, which results in land degradation. According to FGD, a resident of the Majangir zone said, "For the Majangir, the fallow system is just like a dream or an element of the ancient society's history."

Therefore, "the state ownership of land [in the past regimes and in the currently EPRDF-led country] is far from perfect since it restricts the different land rights of use, rent, lease, donation and inheritance for different reasons" to family members. (Weldegebriel Ambaye, 2012: 1) Such arrangement violates the rights of the local Gambella people who have been granted customary land rights for a very long time and now are deprived of the necessary investments on the land indirectly, by the fear of eviction.

\subsection{Change in customary land rights in Gambella}

In Gambella, internal dynamics, which bring changes in the customary land tenure system, are the same with slight variation among the different ethnic groups. (The extent and the speed at which the change takes place can only vary.) In addition to natural occurrences, population pressure contributes to the resource's relative scarcity that culminates in deforestation. The explanation of natural resource scarcity in relation to population pressure dates back to the $18^{\text {th }}$ century when Robert Malthus presented a new demographic theory (Malthus, 1798).

In his theory, Malthus predicted that the imbalance between population and the available scare resources would generate conflicts (and other 'positive checks') to countercheck the 'excess' mouth. Many academic researchers agree that significant population growth is the main drawback in contemporary less developed countries causing fierce competition over fixed natural resources. (Hundie, 2006: 15)

Principally, population pressure creates a lot of unnecessary burdens on the environment; such a pressure could easily invite conflict and put the security of land at risk. It is also believed that because of social ties the concentration of people in one location creates land shortage, which is the case regarding the Gambella peasantry households. The expected conflict is not only intra-ethnic but also inter-ethnic, and thus threatens the state of land tenure security. For instance, in Nuer areas, some villages have been evacuated due to the relative scarcity of natural resources; and people migrate towards Gambela city and its surroundings in search of green pasture, which in turn puts the Anywaa land (Gambela city and its surroundings) under pressure. Such potential fears among the Anywaa brought onto surface the 2002 Anywaa-Nuer conflict in Itang district, which was immediately transformed into a 
full-scale confrontation. Such a contentious issue between the Nuer and the Anywaa appears to be exacerbated due to the government's siding with one of the two.

From the view point of the theories of institutional change, the emergence of new property rights in Gambella can be thought to be a result of strategic conflict between state-sponsored projects and the communities. Accordingly, Knight (1992: 107) argues that "economic actors produce institutions in the process of seeking distributional advantage in the conflicts over substantive benefits."

\subsubsection{External factors}

Another factor is the external one with different facets. The following are some problems created by the external pressure on land tenure security:

(i) Environmental migration (north-south),

(ii) Expansion of urban areas, and

(iii) Conflict in South Sudan (refugees' settlements).

\section{(i) Environmental migration (north-south)}

Environmental migration (north-south migration) is made up of two types of migration: peoples' voluntary migration and government-sponsored migration; which put pressure on the land tenure security system. The involuntary migration of peasants from the north to the south started under the socialist government in the early 1980s and continues to the present day because of the settlement policy to escape the recurrent droughts in the northern part of the country. After peasants discovered the environment as being conducive for agriculture, they started voluntary migration, while those who had settled earlier began inviting their relatives from the north. The settlers built their own villages and gave them name, which goes against the custom of the indigenous community of giving traditional names. Investors from the north put a lot of pressure on the land tenure system, either with expanding the land allocated to them by the local government to the adjacent farmlands of the indigenous people or with purchasing the nearby farmlands from the locals at a very low price and clearing vast areas of forests. The expanded land is not utilized fully and keeps control over the land for speculative purposes.

\section{(ii) Expansion in urban areas}

Although the sub-Saharan region of Africa remains predominantly rural, its urban population has grown far more rapidly than its rural population and continues to do so. Africa's urban population increased nine-fold between 1950 and 2000, while its rural population increased by 265 per cent (United Nations, 2004). Africa, now, has more than 300 million urban dwellers and two-fifths of its population lives in urban areas. Much of the growth of urban population has taken place in informal settlements where land is occupied illegally or land ownership is unclear. In many urban contexts, land titling is not only complex but also involves competing claims, which include politically powerful groups demanding the ownership of informal settlements where large sections of the low-income population live. 
"Rapid urban growth also produces a high demand for well-located sites, including those that are already densely occupied by illegal settlements. The rights of their inhabitants are frequently swept aside when more powerful interests want this land. Rapid urban growth is also having a major impact on peri-urban land values, with rising insecurity for those living on and working such land. Farmers near urban areas in Gambella, where land values are rising very rapidly, face displacement from the conversion of agricultural to building land. [...] Land speculation also disrupts farming and displaces farmers and agricultural laborers" (Toulmin, 2009: 30-31). It appears that the expansion of towns to the peri-urban areas as well as clearing forests for agricultural purposes push peasants and farmers to the margins. Such practice brings environmental degradation.

(iii) Conflict in South Sudan (refugees' settlements)

Of the 18 million refugees and an estimated 22 million internally displaced people in the world today, almost all are in developing countries, where they are associated with a heavy toll on the environment and forests. "The conventional reasoning is straightforward: by creating a sudden, sharp increase in population density, refugees and their herd animals impose a population shock on asylum communities which cannot withstand the strain on resources. Deforestation occurs as refugees seek out firewood and shelter materials, grazing land becomes denuded as refugees' herd animals strain the carrying capacity of the range, water sources cannot support greatly increased utilization and become polluted and depleted, and there is garbage and other waste accumulation around refugee camps (Black, 1994a; Jacobsen, 1994). In addition, refugees are seen as 'exceptional resource degraders' as a consequence of their poverty, short time horizons, lack of local environmental knowledge and traumatized psychological status (Myers, 1993)" (Haileselassie, 2007: 17). Figure 1 below depicts the influx of refugees to the Gambella region with severe consequences on the environment.

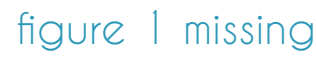


The UNHCR (2019) estimated that the study area had the total number of refugees of 16,455 in Bonga, 34,418 people in Pinyudo, and 10,547 people in Dimma in 1997. The influx of refugees certainly accounts for part of the population growth in the Gambella region. The pressure on land and the environment by the refugees is far higher than the census number would indicate, especially when considering that there has been an additional flow of close to 400,000 refugees in the aftermath of the South Sudan conflict of 2013. Practical problems have been seen and felt in the region with the heavy presence of Southern Sudanese refugees. For instance, the Uduk of the Southern Sudanese refugees in Bonga camp with the approximate number of 19,000 , though they were repatriated back, were found to have imposed immense pressure on the environment and the ecosystem, which has been brought into the state of disequilibrium. Even though these refugees were provided with rations by the UNHCR, they cleared a vast area of land for agricultural purposes; and they complemented their rations by cutting trees for fuelwood and collecting charcoal, a source of energy for cooking and a product for sale. For instance, a significant change in the barren land was observed in the Bonga refugee camp, where the rate of deforestation increased from 0.2 percent in 1990 to 0.7 percent in 2006 (Alemu, 2007). Also hunting activities, which have been seen to be practiced by many residents of the Bonga town and the surrounding communities, pose a threat as apes and monkeys are no longer there and these refugees go as far as where crawling animals for consumption purposes can be found. This process is often negative because the environmental pressures imposed by an influx may lead to loss of woodland and rangeland, increased soil erosion, and a breakdown of soil ecology.

\subsubsection{Urban and rural linkage}

It has been known for many years that the urban and rural linkage takes several forms: economic, administrative, socio-cultural, and political. This is part of the complex relation, which includes a rural-rural link, a small town-small town link (horizontal), a rural-small town link, and a small town-large town link. In an interdependent economy, a sector is linked to other sectors by its direct and indirect purchases and sales.

\subsubsection{Forward linkage}

The southwestern part of the Gambella region has a great potential for the expansion of agriculture and the agro-industry through irrigation. The total cultivable area is $1,209,164$ ha and the net potential irrigable area is about 480,000 ha according to the Baro-Akobo basin study by Selkhozoprom Export (1989). There is a large potential to produce enough food for the inhabitants to achieve self-sufficiency in regions struggling with food deficiency and in the diaspora and to generate export earnings. These days only smaller quantities of corn, rice, beans, palm oil, coffee, tea, tobacco, cassava, sugarcane, etc. are produced. For instance, the area planted for cereals, pulses, and oilseeds was 20,034.51 ha in 2001, while it declined to 16,032.9 ha (according to the information obtained from the records of the Bureau of Agricul- 
ture). Thus, the capacity of rain-fed agriculture to support the urban sector is very low. The usage of old farm equipment along with a small average landholding size of 0.5 hectare results in meager production, which may not produce enough food for the families. The productivity of farmers with the existing arable land has to be enhanced and if this increased productivity leads to a higher supply of food products in the urban sector, farmers' income will increase; in other words, there will be less need for deforestation and more need for leaving some land fallow.

\subsubsection{Backward linkage}

This is a type of linkage that all higher-level sectors/firms have with the lower level sectors or firms. It refers to the inputs and services provided to the agricultural sectors and the agrarian population from various sources including the urban sectors. These inputs can be labor, fertilizers, pesticides, and machinery (e.g., tractor plow). There is no large-scale industry that provides services to the rural economy. The only limited services provided by the government are the provision of fertilizer input to rural people via development agents and the assistance of veterinary technicians and antenatal care and midwifery professionals. The provisions of such services are politically motivated. People with more access to political or party leadership seem to be the ones with preferential treatment.

Most of the backward linkages between industry and agriculture deal with input supply and the services that affect the supply of inputs. An important element of these linkages is the origin of the source of those inputs, i.e., whether they are manufactured or produced locally, or imported.

The nature of the input considers both the long-term and the short-term implications of sourcing via imports versus the local production of raw and intermediate inputs. The larger the portion of inputs produced locally, the greater the multiplier effect from an increase in exports. If a significant portion of the inputs can be produced cost-effectively, at an equal or higher quality than that of the imports, this will have a ripple effect throughout the economy and will lead to greater employment and economic growth. The implication here is that if the employment-generating capacity of the urban or modern sector is high, the rural population will be induced to migrate to nearby urban areas. This will, in turn, reduce high dependency on land and on farming, which helps decrease deforestation.

The nature of the input considers both the long-term and the short-term implications of sourcing via imports versus the local production of raw and intermediate inputs. The larger the portion of inputs produced locally, the greater the multiplier effect from an increase in exports. 
Thus, population pressure due to the refugees' settlements and migration from the northern part of Ethiopia to Gambella has been seen in many places in the region to have caused stresses on the land reinforcing resource depletion, poverty, and conflict. Moreover, the rapid rate of deforestation, as a result of the conversion of marginal land for agricultural purposes, causes soil erosion, the associated problems lead to the decline of soil fertility, and the loss of biodiversity makes livelihood improvement a very challenging task for the Gambella region that relies heavily on agriculture and natural resource products. The enhancement of employment opportunities in urban centers helps lessen the burden on the environment in rural areas.

\subsection{The impact of socio-cultural practice on physical environment perception}

\subsubsection{Grazing land}

Due to the existence of extensive grazing lands in the region, free-grazing is rampant, except in Godere district and the outer fringes of Gambela city. In parts of Godere district, where mixed farming is practiced, there is a shortage of grazing land and each farm household has a plot for practicing controlled grazing. In Abobo, where there are settlers, people have the tradition of protecting grazing land so that it should not be used for other purposes. Due to the shortage of grazing land in the outer fringes of Gambella district, farmers graze cattle on crop residue.

\subsubsection{Water}

Settlement along the rivers is the norm for indigenous people living in the region since their livelihood depends on cultivating flood-recession crops and fishing along the banks of the rivers. A "free watering right" of washing, boating, drinking, and watering the animals is guaranteed to the community but with some restrictions in fishing activities. In fact, there is ethnic tension among sedentary farmers and agropastoralist communities along big rivers. Among other implications, the right to water usage has an impact on settlement patterns. If the human right to water is not guaranteed, people will not be able to settle in certain areas or undertake long-term investments, such as the plantation of perennial crops to maintain tenure security.

\subsubsection{Forest}

Forests are accessible to the local people, and this enables them to cut trees for cooking purposes, construction, and selling wood. Even the naturally intact forest that belongs to the government in Gog and Godere is accessible. Farmers burn off the forests in need of farmland and timber from big trees. The practice of shifting cultivation by the Majangir allows the preparation of land for cultivation. Although most rural people benefit from the forests, the inhabitants are not in favor of the state's forest plantation efforts due to the fact that they have to face the problem of the shortage of grazing land, the 'shrinking of land,' and the proliferation of crop fields.

Grazing land, water, and forests are the primary resources of agricultural production and are essential to maintain human life and well-being (FAO, 1995). As of 
now, the Gambella region is believed to be confronted with an environmental crisis of huge magnitude, greater than ever before. The rate of land degradation, the loss of soil fertility due to erosion, and the depletion of organic matter and nutrients are faster than the rate of regeneration. In spite of all the attempts to reverse these trends, the forest resource and the vegetation cover of the region have been depleting alarmingly, which causes land degradation and a shortage of firewood and timber supply.

\subsection{Land-use systems and indigenous practice}

According to the Ministry of Agriculture (Woody Biomass Inventory and Strategic Planning Project, 2001), the land-use system of Gambella Regional State comprises five systems: four cultivation and one pastoral system.

\subsubsection{The cereal cultivation system of the Anywaa, the Opo, and the Komo people} Different types of cultivation are being practiced by the indigenous communities inhabiting the region. The Anywaa, the Opo, and the Komo people cultivate the banks and levees of the main rivers rather than the woodlands in the interfluves. Maize, bean, and sorghum are produced. A maize parcel of an average size of 1-2 hectares is followed by 1 hectare of long season sorghum. First maize and bean crops are grown on the wetter soils where there is residual moisture. The second crop is grown during the rainy season on the high and better-drained levee soils along with sorghum and beans. Fishing is an important source of food. Hunting on the plains and in the forest edges is carried out in the dry season; fire is also used to frighten animals (ENTRO, 2008).

The Anywaa depend on cultivating flood-recession crops and shifting cultivation is their main livelihood strategy. In fact, the Anywaa are traditional agriculturalists who have taken advantage of their proximity to the Baro, Akobo, Gilo (Pibor), and Alwero rivers to cultivate flood-tolerant and rain-fed crops. Since they live above the levee, they rely on growing crops in the same place by harvesting rain-fed crops before the river swells and others after the flood recedes.

\subsubsection{The agro-pastoral system of livestock production of the Nuer}

The Nuer are predominantly cattle breeders; they also cultivate flood-recession maize and sorghum to supplement their diet of milk and blood. Families own the cattle jointly; a son may obtain permission from his father to use the cattle to pay the bridewealth. The Nuer are agro-pastoralists, practicing semi-sedentary farming. They also depend on the seasonal movement of the livestock during the dry and the wet season. During the rainy season they move to the upland areas in search of green pasture and evacuate the flood zone, and then return to the riverbank during the dry season to settle for a longer period. The Nuer also migrate to the frontiers during dry seasons in search of pasture for the cattle. Such movement concerns only youngsters (male and female), the elderly (men and women) remain at the riverbanks to take care of agricultural products and nurse the sick and the aged cattle around homesteads (ENTRO, 2008). 
The Nuer were originally "pure" pastoralists who at the later days of the diversification of agriculture have become agro-pastoralists. The agro-pastoralist Nuer inhabit the vast forests in the uplands, the savannah grasslands, and the seasonally flooded plains of Jiokow, Akobo, and Itang districts at the riverbank. It is to be noted that because of the scattered forests there is no serious tsetse challenge in these areas.

\subsubsection{The shifting cultivation system of the Majangir}

About some 2,400 farm families of the Majang people are found to practice a sophisticated system of weed mulching and forest fallowing. About $72 \%$ of them live mainly in Godere district, deep below the Keffa highland, and in the high forests on the escarpment and the adjoining foothills. Among these groups, the use of mulch to suppress weed growth extends the period of cultivation by some two to four years (ENTRO, 2008). Thus, the Majangir appear to have partially solved the problem of weed infestation.

The Majangir subsistence system depends basically on the shifting cultivation of maize and sorghum, hunting, fishing, and beekeeping. No livestock other than chickens is kept because of the high prevalence of the tsetse fly. They gather forest products, wild plants except for mushrooms, fresh greens, wild yam, and wild coffee (only leaves and twigs, not berries).

The most consumed staple crops are maize and sorghum, with some taro, yam (several species), and pumpkin. Crops cultivated for consumption include sesame, beans, peas, pumpkin, taro leaves, and some introduced crops including sweet potato, sweet cassava, enset, and sugarcane, but none of these latter crops are important. Spices are grown to flavor coffee (ENTRO, 2008).

Due to constant floods and the clearing of vast tracks of forests, soil erosion is the most dangerous ecological process observed in Gambella. Soil resources are the basis of agricultural production and provide several ecosystem services and food for the region's people. Therefore, traditional conservation measures such as tree-planting and leaving the land fallow are being considered to help maintain the fertility of the land (ENTRO, 2008).

\section{Conclusion and policy implications}

This paper considered the effect of land tenure policy on the environment, in general, and deforestation, in particular; three desirable properties of an appropriate land tenure system were also identified. This was followed by the analysis of the land tenure systems of the various ethnic groups that reside in the study area. The overall impression is that the prevailing land tenure system in the study area is not conducive to the retention of forest cover; nor is it appropriate for tree-planting. Besides ethnic differences, external factors that affect forest cover and reforestation were highlighted. These external factors include migrants from the Ethiopian highlands, the expansion of the urban areas as well as migrants from South Sudan, who came as a result of conflicts within Sudan and after the eruption of violence during the 2013 South Sudanese Civil War. Related constraints include issues of both urban-rural 
and forward-backward linkages. The availability of and the accessibility to water, forests, and grazing land were also indicated. In general, in this paper, I have tried to consider various socio-economic and cultural settings in the study area as one should have some knowledge of the socio-economic background of this area.

The population of Ethiopia has increased rapidly over the past fifty years, and according to the Federal Central Statistical Agency (CSA), the current estimate is about 100 million people. The impact of this high population growth on the demand for farmland has not only intensified but has also coupled with a fragmented policy on the land tenure regime that has led to high deforestation and land degradation with far-reaching implications on the environment. Ethiopia's federal government should formulate and implement economically viable land reform policies to ensure that the farmers feel an emotional attachment to the land they cultivate. Therefore, regional governments should direct their attention toward designing a clear policy on land tenure security that acknowledges private ownership, enhances the positive relationship between man and the ecosystem, and encourages peasants and farmers to make long-term investments in land that can lead to improved living conditions for the poor and increased agricultural investment.

\section{References}

Benneh, G. (1987). Land Tenure and Agroforestry Land Use Systems in Ghana. In: Raintree, J. B. (Ed). Land, Trees, and Tenure. International Centre for Research in Agroforestry, Nairobi, 163-138.

Bereket K. (2002). Land tenure and common pool resources in rural Ethiopia: a study based on fifteen sites. African Development Review 14 (1), 162-164.

Berhanu N., Berhanu A., and Seyoum G. S. (2003). Current Land Policy Issues in Ethiopia. Ethiopian Economic Policy Research Institute, Addis Ababa.

Beyene C. (2017). Contending views on land tenure system in Ethiopia: historiographical essay. African Journal of History and Culture 9 (1), 1-6.

Binayaw T. (2015). Historiographical review of the current debate on Ethiopia land tenure system. African Journal of History and Culture 7 (2), 44-51.

Black, R. (1994). Forced migration and environmental change: the impact of refugees on host environment. Journal of Environmental Management 42, 261-277.

Central Statistical Agency of Ethiopia. (CSA). (1994).

Crisologo-Mendoza, L. and Van de gaer, D. (2001). Population growth and customary land law: the case of Cordillera villages in the Philippines. Economic Development and Cultural Change 49 (3), 631-658.

Deininger, K. and Binswanger, H. (1999). The evolution of the World Bank's land policy: principles, experience, and future challenges. The World Bank Research Observer 14 (2), 247-276.

Deininger, K. and Feder, G. (2002). Land Institutions and Policy: Key Messages of the Policy Research Report. Workshop on Land Institutions and Land Policy Consultations for a World Bank Policy Research Report. Kampala, Uganda, April 29-May 2, 2002.

Dessalegn R. (1984). Agrarian Reform in Ethiopia. Scandinavian Institute of African Studies, Uppsala. 
Dessalegn R. (1999). Land and Rural Poverty in Ethiopia. DEFID Workshop on Land Rights and Sustainable Development in Sub-Saharan Africa: Lessons and Ways Forward in Land Tenure Policy. Sunningdale, United Kingdom, February 16-19, 1999.

Eastern Nile Technical Regional Office. (ENTRO). (2008). BARO-AKOBO-SOBAT and White Nile Multipurpose Water Resource Development Study Project-Annex 1. ENSAPIDEN-ENTRO, Addis Ababa.

Ethiopian Economic Association/Ethiopian Economic Policy Research Institute (EEA/ EEPRI). (2002). Land Tenure and Agricultural Development in Ethiopia. EEA Publication, Addis Ababa.

Federal Democratic Republic of Ethiopia. (FDRE). (1995). The Constitution of the Federal Democratic Republic of Ethiopia Proclamation No. 1/1995. Federal Negarit Gazeta 1 (1), 1-30.

Food and Agriculture Organization. (FAO). (1995). The State of Food and Agriculture. Food and Agriculture Organization of the United Nations, Rome.

Haileselassie G. T. (2007). The Need for Integrated Natural Resource Management (INRM) in Refugee Settlement Areas: the Case of Eritrean Refugees in and around Shimelba Camp, Tigray National Regional State, Ethiopia. Unpublished MA Thesis. Addis Ababa University, Addis Ababa.

Hosaena G. (2010). Land Policy Reform and Land Rental Markets in Ethiopia: Equity, Productivity and Welfare Implications. PhD Thesis. Norwegian University of Life Sciences, Ås.

Hundie, B. (2006). Property rights among Afar pastoralists of northeastern Ethiopia: forms, changes and conflicts. SAGA Publications. https://www.saga.cornell.edu/saga/ ilri0606/35hundie.pdf [01.31.2020]

Jacobsen, K. (1994). The Impact of Refugees on the Environment: a Review of the Evidence. Refugee Policy Group, Washington DC.

Knight, J. (1992). Institutions and Social Conflict: Political Economy of Institutions and Decisions. Cambridge University Press, Cambridge.

Laws, S., Harper, C., and Marcus, R. (2003). Research for Development. SAGE Publications Ltd., Thousand Oaks, CA.

Malthus, T. R. (1798). An Essay on the Principles of Population, as it Affects the Future Improvement of Society. J. Johnson, London.

Myers, N. (1993). Environmental refugees: how many ahead? Climate Alert 6 (5), 2-3.

Place, F. and Otsuka, K. (2000). Population pressure, land tenure, and tree resource management in Uganda. Land Economics 76, 233-251.

Quisumbing, A. R. and Otsuka, K. (2001). Land, Trees, and Women: Evolution of Land Tenure Institutions in Western Ghana and Sumatra. (Research Reports 121) International Food Policy Research Institute (IFPRI), Washington DC.

Quisumbing, A.R., Payongayong, E., Aidoo, J. B., and Otsuka, K. (2001). Women's land rights in the transition to individualized ownership: implications for tree resource management in western Ghana. Economic Development and Cultural Change 50, 157-182.

Selkhozoprom Export. (1990). Baro-Akobo Basin Master Plan Study of Water and Land Resources of the Gambella Plain. Ethiopian Valleys Development Studies Authority, Moscow.

Shepherd, G. (1991). The communal management of forests in the semi-arid and sub-humid regions of Africa: past practice and prospects for the future. Development Policy Review 9, 151-176.

Shimelles T., Islam, K. M. Z., and Parviainen, T. (2009). Effects of Land Tenure and Property Rights on Agricultural Productivity in Ethiopia, Namibia and Bangladesh. Discussion Paper No.33. Department of Economics and Management, University of Helsinki, Helsinki. 
Stauder, J. (1971). The Majangir: Ecology and Society of a Southwest Ethiopian People. Cambridge University Press, Cambridge.

Toulmin, C. (2009). Securing land and property rights in sub-Saharan Africa: the role of local institutions. Land Use Policy 26, 27-54.

UNHCR Gambella Registration Unit. (2019).

United Nations. (2004). World Urbanization Prospects: the 2003 Revision. Department of Economics and Social Affairs, ESA/P/WP.190, United Nations Population Division, New York.

Weldegebriel Ambaye, D. (2012). Land Rights in Ethiopia: Ownership, Equity, and Liberty in Land Use Rights. FIG Working Week, Knowing to manage the territory, protect the environment, evaluate the cultural heritage, Rome, Italy, May 6-10, 2012.

Woody Biomass Inventory and Strategic Planning Project. (2001). A Strategic Plan for the Sustainable Development Conservation and Management of the Woody Biomass Resources. Ministry of Agriculture, Addis Ababa. 